\title{
Efficient aquatic bacterial metabolism of dissolved low-molecular-weight compounds from terrestrial sources
}

\author{
Martin Berggren ${ }^{1}$, Hjalmar Laudon ${ }^{2}$, Mahsa Haei ${ }^{1}$, Lena Ström ${ }^{3}$ and Mats Jansson ${ }^{1}$ \\ ${ }^{1}$ Department of Ecology and Environmental Science, Umea University, Umea, Sweden; ${ }^{2}$ Department of Forest \\ Ecology and Management, Swedish University of Agricultural Sciences, Umea, Sweden and ${ }^{3}$ Department of \\ Physical Geography and Ecosystems Analysis, Lund University, Lund, Sweden
}

\begin{abstract}
Carboxylic acids (CAs), amino acids (AAs) and carbohydrates (CHs) in dissolved free forms can be readily assimilated by aquatic bacteria and metabolized at high growth efficiencies. Previous studies have shown that these low-molecular-weight (LMW) substrates are released by phytoplankton but also that unidentified LMW compounds of terrestrial origin is a subsidy for bacterial metabolism in unproductive freshwater systems. We tested the hypothesis that different terrestrially derived $\mathrm{CA}, \mathrm{AA}$ and $\mathrm{CH}$ compounds can offer substantial support for aquatic bacterial metabolism in fresh waters that are dominated by allochthonous dissolved organic matter (DOM). Drainage water from three catchments of different characters in the Krycklan experimental area in Northern Sweden were studied at the rising and falling limb of the spring flood, using a 2-week bioassay approach. A variety of CA, AA and $\mathrm{CH}$ compounds were significantly assimilated by bacteria, meeting 15-100\% of the bacterial carbon demand and explaining most of the observed variation in bacterial growth efficiency (BGE; $R^{2}=0.66$ ). Of the 29 chemical species that was detected, acetate was the most important, representing $45 \%$ of the total bacterial consumption of all LMW compounds. We suggest that LMW organic compounds in boreal spring flood drainage could potentially support all in situ bacterial production in receiving lake waters during periods of weeks to months after the spring flood.
\end{abstract}

The ISME Journal (2010) 4, 408-416; doi:10.1038/ismej.2009.120; published online 12 November 2009

Subject Category: geomicrobiology and microbial contributions to geochemical cycles

Keywords: freshwater; growth efficiency; heterotrophic bacteria; low-molecular-weight DOM

\section{Introduction}

Aquatic bacterial degradation of dissolved organic matter (DOM) is a key process for cycling of carbon in the biosphere, and bacterial production based on DOM provides an important subsidy to aquatic microbial food chains (Azam et al., 1983; Jansson et al., 2007). Bacterial biomass and activity are positively correlated with phytoplankton production in freshwater systems of different trophic states (Cole et al., 1988), indicating that primary production is a major DOM source for bacteria. Release of labile low-molecular-weight (LMW) DOM through phytoplankton exudation and cell lysis, mainly as amino acids (AAs) and carbohydrates (CHs), and also as carboxylic acids (CAs) (Hellebust, 1974; Fogg, 1983), is a possible mechanism for phyto-

Correspondence: M Berggren, Department of Ecology and Environmental Science, Umeå University, Linnaeus väg 6, Umeå SE-901 87, Sweden.

E-mail: martin.berggren@emg.umu.se

Received 28 July 2009; revised 8 October 2009; accepted 10 October 2009; published online 12 November 2009 plankton stimulation of bacterial growth (Chen and Wangersky, 1996). These LMW compounds can be readily assimilated by bacteria (Tranvik and Jørgensen, 1995; Bertilsson and Tranvik, 1998; Rosenstock and Simon, 2001) and are metabolized with a bacterial growth efficiency (BGE) of $\geqslant 0.4$ (del Giorgio and Cole, 1998), implying that a large share of the assimilated carbon is allocated to growth.

However, many unproductive streams and lakes have low rates of autochthonous carbon fixation and most DOM comes from terrestrial sources (allochthonous organic carbon). This DOM has been partially degraded in terrestrial soil systems and is considered a poor substrate for bacteria because of chemical recalcitrance (Tranvik, 1998). Moreover, little of the allochthonous DOM is believed to contribute to bacterial growth because of the low community BGE $(<0.1)$ that is observed in systems dominated by allochthonous carbon sources (del Giorgio and Cole, 1998; Kamjunke et al., 2006). Nevertheless, allochthonous DOM is an important substrate for bacteria in many unproductive lakes, evident from the fact that ambient phytoplankton 
production is too low to support the observed bacterial carbon demand (Jones, 1992; Karlsson et al., 2002). Radio-tracer techniques have confirmed that allochthonous carbon can make up the major share of bacterial carbon contents in humic lake water (Kritzberg et al., 2006). Moreover, bacterial biomass and activity in unproductive lakes are often positively correlated with concentrations of allochthonous DOM (Jones, 1992; Bergström and Jansson, 2000; Jansson et al., 2000). High support of bacterial metabolism by allochthonous DOM can be an effect of large amounts of DOM compensating for the low specific degradation rates (Wetzel, 1995) or that allochthonous DOM can be modified by ultraviolet radiation producing labile LMW DOM (Bertilsson and Tranvik, 1998). Another, largely unexplored, possibility is that parts of the terrestrial DOM export are more labile than previously thought.

Terrestrial export of labile LMW DOM can be an important subsidy for aquatic bacterial metabolism. In River Satilla (United States), strongly dominated by terrestrial DOM (Hopkinson et al., 1998), bacterial use of LMW DOM was 4-10 times higher than the bacterial use of high-molecular-weight DOM (Covert and Moran, 2001). Strong dependence on LMW DOM was also shown for heterotrophic metabolism in water from thawing permafrost soils (Roehm et al., 2009). Recent studies in the Krycklan catchment in boreal Sweden indicated that drainage from forested land supported a short-term bacterial consumption of LMW DOM metabolized with high (up to 0.4) growth efficiency (Berggren et al., 2007; Agren et al., 2008a). Further, this labile DOM fraction stimulated BGE and bacterial production for periods of 1-2 months during in situ lacustrine conditions (Berggren et al., 2009b). Similarly, Jonsson et al. (2007) estimated that input of allochthonous LMW DOM in the form of CA and $\mathrm{CH}$ was sufficient to cover at least $30 \%$ of the annual bacterial carbon demand in a lake in northern Sweden.

Consequently, allochthonous DOM input into streams and lakes may support efficient bacterial production to a greater extent than previously believed through uptake of LMW DOM. To explore this possibility further, we tested the hypothesis that the aquatic bacterial carbon demand and BGE is controlled by the concentration of LMW DOM after its release from soils into surface water, mainly through its content of $\mathrm{CA}, \mathrm{AA}$ and $\mathrm{CH}$. Using a 2-week bioassay approach, this hypothesis was tested with headwater DOM from three catchments of different characters in the Krycklan area, sampled at the rising and falling limb of the spring flood hydrograph. We argue that the bacterial consumption of simple, free organic LMW compounds of terrestrial origin can meet a significant share of the bacterial carbon demand and explain patterns of bacterial metabolism over space and time.

\section{Methods}

Study sites

The study was carried out in the Krycklan catchment at the Vindeln Experimental Forests $\left(64^{\circ}, 14^{\prime}\right.$ $\left.\mathrm{N}, 19^{\circ} 46^{\prime} \mathrm{E}\right)$ in northern Sweden, where hydrological and biogeochemical studies have been performed for several decades. We selected the two most intensively studied headwater streams of the area, Västrabäcken draining a 13-ha forested catchment and Kallkällsmyren draining a 19-ha miredominated catchment. The average water renewal time in the headwater streams was ca. $2 \mathrm{~h}$ during spring flood (Laudon, unpublished) and previous studies (Schumacher et al., 2006; Ågren et al., 2007) showed that terrestrial DOM totally dominated the DOM pool of these streams. We also included the outlet of the nearby small humic lake, Stortjärnen, with a 95-ha mixed catchment (ca. 1/3 mire and 2/3 forest) for the possibility to assess how lake passage can affect the LMW content of stream water. Although this lake outlet could, in principle, have been influenced by autochthonous sources of LMW DOM, studies in similar lakes in the region (that is, highly colored small lakes with relatively short water renewal time) have shown that primary production is very low and does not seem to affect DOM bulk properties or use by bacteria (Berggren et al., 2009b). We therefore consider that DOM characteristics and use in the Stortjärnen outlet reflect possible changes caused by lake metabolism of DOM. The forest component of the catchments was dominated by Norway Spruce (Picea abies). Mires were dominated by peat forming Sphagnum species and could be categorized as ombrotrophic or oligotrophic minerogenic. The annual precipitation of the area is $600 \mathrm{~mm}$, of which $35 \%$ falls as snow between November and April. All the snow stored in winter melts over a 2-month period in spring (see Ågren et al., 2007 for detailed catchment characteristics).

\section{Sampling and analyses}

We chose the snow melt period for this study. Snow melt causes a high flow episode in April to May every year in most boreal areas, carrying $\geqslant 50 \%$ of the total annual runoff and DOM transport. Moreover, the spring flood can cause pronounced stimulation of bacterial production in boreal lakes (Bergström and Jansson, 2000) with spinoff effects on the pelagic food webs (Drakare et al., 2002). The streams and the lake outlet were sampled once in early spring (March 14) at the beginning of the rising limb and once in late spring (May 22) at the end of the falling limb of the spring flood hydrograph of 2007. Water was collected in 2.01 acid-washed and stream water-rinsed high-density polyethylene bottles that were kept dark and cool until arrival at the laboratory. The samples were thereafter equilibrated with standard air $(78 \%$ nitrogen, $21 \%$ oxygen and 
$0.03 \%$ carbon dioxide) to remove methane and supersaturation of carbon dioxide. They were then subsampled into $22 \mathrm{ml}$ gas-tight glass bottles, leaving a $12-\mathrm{ml}$ headspace flushed with standard air. All bottles were incubated in the dark at $20^{\circ} \mathrm{C}$.

Triplicates of the $22 \mathrm{ml}$ incubation bottles were analyzed for bacterial production every second day and bacterial respiration every fourth day, over a period of 2 weeks, starting approximately $24 \mathrm{~h}$ after sealing of the bottles. Each incubation bottle was used only once and then discarded. Bacterial respiration was measured as dissolved inorganic carbon production on a PerkinElmer (Waltham, MA, USA) gas chromatograph-flame ionization detector, with a headspace auto-sampler that operated directly on the incubation bottles (Berggren et al., 2007). Before analysis, the samples were acidified and shaken to achieve a known equilibrium between headspace and water. As bacteria constitute ca. 90\% of total planktonic biomass in humic water during dark incubation (Daniel et al., 2005), we assumed that the measured dark dissolved inorganic carbon production represented the respiration of bacteria. Bacterial production was measured in $1.2 \mathrm{ml}$ aliquots with the leucine incorporation method (Smith and Azam, 1992; Karlsson et al., 2002).

Filtered samples $(0.45 \mu \mathrm{m}$, Millipore, Bedford, MA, USA) for DOM analysis were frozen directly after arrival to the laboratory and analyzed later with a Shimadzu (Kyoto, Japan) TOC- $\mathrm{V}_{\mathrm{CPH}}$ analyzer. Absorbance spectra were measured directly at the incubation start, and again after 14 days of incubation, on filtered samples ( $0.45 \mu \mathrm{m}$, Millipore) in $1 \mathrm{~cm}$ quartz cuvettes with a Hewlett Packard (Palo Alto, CA, USA) 8452A diode array spectrophotometer.

Carboxylic acid (CA), $\mathrm{AA}$ and $\mathrm{CH}$ were sampled by filtering water through $0.22-\mu \mathrm{m}$ Millipore filters at the incubation start, at the same time as the incubation bottles were sealed, and again after 14 days of incubation. These samples were kept deep-frozen from sampling to analysis. Determination of CA, AA and $\mathrm{CH}$ was carried out at Lund University using liquid chromatography-ionspray tandem mass spectrometry. The instrumental setup consisted of a Dionex (Sunnyvale, CA, USA) ICS2500 liquid chromatography (LC) system directly coupled to an Applied Biosystems (Foster City, CA, USA) 2000 Q-Trap triple quadrupole mass spectrometer (MS). CA, AA and CH can occur combined or in complexes with DOM, forming molecules of higher molecular weight of various labilities. In this study we measured only the free, simple LMW forms of $\mathrm{CA}, \mathrm{AA}$ and $\mathrm{CH}$.

The LC system was especially equipped to meet the separation requirements of each of the three compound groups. LC separation of CA was performed using the Dionex IonPac AS11 analytical column, AG11 guard column and the anion selfregenerating suppressor-Ultra suppressor column to de-salt the mobile phase ( $\mathrm{NaOH}$ gradient from 1 to $60 \mathrm{~mm}$ over $8 \mathrm{~min}$ ) before the MS analysis. LC separation of $\mathrm{CH}$ were performed using the Dionex CarboPac PA20 analytical column, AminoTrap guard column to remove AA during the CA analysis and the anion self-regenerating suppressor-Ultra suppressor column to de-salt the mobile phase (NaOH gradient from 4 to $80 \mathrm{mM}$ over $20 \mathrm{~min}$ ). LC separation of AA was performed using a Sielc (Prospect Heights, IL, USA) Primesep 200 analytical column and a mobile phase of $30 \%$ acetonitrile and $70 \%$ deionized water combined with a gradient of trifluoroacetic acid (0.05-0.30\% over $6 \mathrm{~min})$.

The MS was operated in positive ion mode for AA and in negative ion mode for $\mathrm{CA}$ and $\mathrm{CH}$ analysis. Nitrogen was used as curtain and collision gas. The general MS conditions were as follows: nebulizer gas $=45 \mathrm{psi}$, curtain gas $=15 \mathrm{psi}$, heater gas $=45 \mathrm{psi}$, heater temperature $=5500^{\circ} \mathrm{C}$, collision gas $=5 \mathrm{psi}$ and ion spray voltage $=4500 /-4500$ (depending on mode). Declustering potential, entrance potential, collision energy and collision cell exit potential was individually set for each compound to maximize the signal output. For tandem MS analysis, the protonated molecule $[\mathrm{M}+\mathrm{H}]^{+}$(AA analysis) and the deprotonated molecule $[\mathrm{M}-\mathrm{H}]^{-}$(CA and $\mathrm{CH}$ analysis) was used as the parent ion and the ion transitions was chosen to maximize the signal output. When combined, the LC separation and MS analysis resulted in a complete separation of all CAs and CHs and all AAs, except Leu and Ile that has the same element composition and molecular weight.

Owing to a missing sample, complete analyses could not be conducted on the incubation of lake outlet water from May 22. The experiments reported in this study to represent the lake Stortjärnen outlet at the falling limb of the spring flood hydrograph are based on analyses of water samples that were collected on April 26. Although the alternative date represented an earlier stage of the falling limb, less than 2 weeks from peak flow, stream concentrations of the different compounds of CA, AA and $\mathrm{CH}$ at the lake outlet were very similar to those on May 22.

\section{Calculations, statistics and assumptions}

Bacterial assimilation of different organic LMW compounds was calculated as the concentration difference between the beginning and the end of the 2 -week incubations. The significance of reductions in concentrations was tested by performing paired $t$-tests, using the six main samples (forest, mire or lake in early and late flood) as replicates. As we specifically hypothesized reduced concentrations, one-tail significance tests were applied. It was assumed that reductions in concentrations were because of bacterial consumption and not abiotic processes (Tranvik and Jørgensen, 1995). This assumption was supported by a test in which we restored the initial concentrations of acetate (the compound that dominated the assumed bacterial 
consumption) in post-incubated samples and observed a return of the initial high values of bacterial production. A total of $12 \mu \mathrm{M}$ of acetate was added to triplicates of Västrabäcken samples and $6 \mu \mathrm{M}$ of acetate to triplicates of Kallkällsmyren samples. The treatment had its largest effect 2 days after addition, when the average bacterial production was 2.7 times higher in treatment than control samples (paired $t$-test; $t=7.2, \quad n=6$, $P<0.01$ ). There was a significant treatment effect at 1 and 2 days after acetate addition, but not after 3 , 5 or 7 days.

Two measures were used to describe the bacterial metabolism: bacterial carbon demand (BCD) and BGE. BCD, which yields the total amount of carbon needed to sustain bacterial anabolic and catabolic processes, was calculated as the sum of bacterial production and bacterial respiration. BGE, which is the degree to which BCD supports bacterial production, was calculated as the ratio between bacterial production and BCD. Bacterial production and respiration at the beginning and at the end of the incubations were assessed as previously described (Berggren et al., 2007). Total bacterial production and respiration during the incubations were calculated from average leucine incorporation per day (mean of all data points) and the overall increase in dissolved inorganic carbon per day (slope of linear regression lines) multiplied with the number of incubation days.

The ratio between absorbance of 254 and $365 \mathrm{~nm}$ (a254/a365) was calculated and used as an index of the DOM character (Ågren et al., 2008b). Absorbance spectra tend to change with increased average molecular weight of DOM. A higher value of a254/ a365, compared with a lower value, indicates lower average molecular weight of the DOM (Strome and Miller, 1978; Dahlén et al., 1996). In previous studies from the region, a254/a365 was positively correlated with BGE (Berggren et al., 2007, 2009a).

\section{Results}

Initial concentrations of $\mathrm{CA}, \mathrm{AA}$, and $\mathrm{CH}$ were generally higher in the forest stream compared with the peat mire outlet, despite higher total DOM concentrations in the mire drainage (Table 1). The total amount of LMW DOM, defined as the sum of $\mathrm{CA}$, AA and $\mathrm{CH}$, was $0.56-1.01 \mathrm{mg} \mathrm{CL}^{-1}$ in the forest drainage, $0.39-0.43 \mathrm{mg} \mathrm{CL}^{-1}$ in the mire drainage and $0.21-0.91 \mathrm{mg} \mathrm{CL}^{-1}$ in the lake outlet water. Differences in LMW DOM between forest and mire samples were largest in early spring, when the initial concentration of total LMW DOM in the forest stream was $240 \%$ of that in the mire stream. The majority of the LMW DOM (50-90\%) consisted of CA, whereas AA $(5-32 \%)$ and $\mathrm{CH}(5-19 \%)$ represented smaller shares (Table 1). The composition of compounds within CA, AA, and CH (Figure 1) was similar for the three study sites.
Concentrations of the different free organic LMW compounds were much higher at the start of the 2-week incubations, compared with after incubation (Table 1). Of the different CAs, concentrations of acetic, lactic and citric acids decreased significantly, by $81-100 \%$ (Figure 1a). The reduction of formic acid was not more than marginally significant $(P<0.10)$ as formic acid was only present in two of the samples. When present, however, formic acid was completely consumed. Tartaric, succinic, oxalic, malic and glycolic acids were never consumed by the bacteria to a significant extent. Acetic acid was the quantitatively most important CA, making up $60 \%$ of the initial concentrations of CA and $65 \%$ of the total bacterial CA consumption. The 15 different AAs that were found in the streams were highly labile (Figure 1b). Their concentrations decreased by $66 \%$ to $100 \%$ during the incubations and most of these reductions were significant. Asparagine and serine were the two dominant species, collectively constituting $50 \%$ of the total AA initial concentration and $46 \%$ of the AA consumption. Among $\mathrm{CHs}$, glucose and fructose were equally dominant, together making up $84 \%$ of the total $\mathrm{CH}$ concentration and $81 \%$ of the consumption of $\mathrm{CH}$. When occasionally present, concentrations of mannitol, mannose and sucrose were also reduced during incubation, although not significantly.

Bacterial carbon demand amounted to a similar share of the total DOM pool in the different stream types (Table 1). The total BCD during the incubations was, on average, $6.0 \%$ (s.d. $=1.0)$ of DOM, which corresponds to $0.43 \% \mathrm{~d}^{-1}$ (s.d. $=0.07$ ), and there was a significant positive correlation between total BCD and DOM $\left(R^{2}=0.66, n=6, P<0.05\right)$. The BGE showed a larger variability than BCD-DOM, with values varying fourfold between 0.11 and 0.40 (Table 1). BGE at the start of the incubation was twice as high in the forest stream compared with the mire outlet stream in the early stage of the spring flood. In late spring, there was no difference. Highest BGE values were recorded in the early spring samples from the forest stream and the lake outlet. Initial incubation values of BGE were significantly higher than the final values (paired $t$-test; $t=4.6, n=6, P<0.01)$. The average drop in BGE from the beginning to the end of the incubation experiments was 0.11 units.

Although BCD was proportional to the total amount of DOM, BGE was related to the character of the organic carbon. There was a significant positive relationship between BGE and the free LMW compounds $\left(R^{2}=0.66, \quad n=12, \quad P<0.01\right.$; Figure 2). This relationship was mainly attributed to CA and, in particular, acetic acid. The relationship between acetic acid alone and BGE was as strong as $R^{2}=0.59$ ( $n=12, P<0.01$; data not shown). There was also a significant positive correlation between BGE and the absorbance ratio a254/a365 $\left(R^{2}=0.45, n=12, P<0.05\right.$; data in Table 1$)$. This ratio followed the variations in the amount of free 
Table 1 The concentration and character of different DOM fractions, and measures of bacterial metabolism, in samples from three different types of streams during different stages of a boreal spring flood

\begin{tabular}{|c|c|c|c|c|c|c|}
\hline \multirow[t]{2}{*}{ Variables } & \multicolumn{2}{|c|}{ Forest stream } & \multicolumn{2}{|c|}{ Mire outlet } & \multicolumn{2}{|c|}{ Lake outlet } \\
\hline & Early spring & Late spring & Early spring & Late spring & Early spring & Late spring \\
\hline \multicolumn{7}{|l|}{ Total DOM } \\
\hline $\mathrm{DOM}\left(\mathrm{mg} \mathrm{CL}^{-1}\right)$ & 12.0 & 16.6 & 24.3 & 24.4 & 19.1 & 19.5 \\
\hline a254/a365 & $4.77 \rightarrow 3.99$ & $4.69 \rightarrow 4.20$ & $4.00 \rightarrow 3.74$ & $4.00 \rightarrow 3.88$ & $4.11 \rightarrow 3.85$ & $3.97 \rightarrow 3.77$ \\
\hline \multicolumn{7}{|c|}{ LMW DOM and its components } \\
\hline LMW DOM (mg CL $\left.{ }^{-1}\right)$ & $1.01 \rightarrow 0.11$ & $0.56 \rightarrow 0.15$ & $0.43 \rightarrow 0.13$ & $0.39 \rightarrow 0.19$ & $0.91 \rightarrow 0.17$ & $0.21 \rightarrow 0.19$ \\
\hline $\mathrm{CA}\left(\mu \mathrm{g} \mathrm{CL}^{-1}\right)$ & $780.9 \rightarrow 101.7$ & $278.3 \rightarrow 127.7$ & $268.8 \rightarrow 115.1$ & $340.2 \rightarrow 159.8$ & $819.9 \rightarrow 145.6$ & $160.3 \rightarrow 160.4$ \\
\hline $\mathrm{AA}\left(\mu \mathrm{gCL}^{-1}\right)$ & $101.9 \rightarrow 11.9$ & $178.8 \rightarrow 7.8$ & $78.4 \rightarrow 9.2$ & $27.2 \rightarrow 13.9$ & $47.7 \rightarrow 4.5$ & $37.2 \rightarrow 15.1$ \\
\hline $\mathrm{CH}\left(\mu \mathrm{gCL}^{-1}\right)$ & $127.2 \rightarrow 0.0$ & $107.5 \rightarrow 13.4$ & $79.6 \rightarrow 4.0$ & $26.3 \rightarrow 15.3$ & $45.5 \rightarrow 20.5$ & $16.1 \rightarrow 16.1$ \\
\hline \multicolumn{7}{|l|}{ Bacterial metabolism } \\
\hline $\mathrm{BCD}\left(\mu \mathrm{g} \mathrm{CL}^{-1} \mathrm{~d}^{-1}\right)$ & $55.2 \rightarrow 45.8$ & $67.6 \rightarrow 58.7$ & $156.3 \rightarrow 140.2$ & $96.9 \rightarrow 81.7$ & $91.5 \rightarrow 72.1$ & $88.2 \rightarrow 80.2$ \\
\hline BCD-DOM (\% per day) & $0.46 \rightarrow 0.38$ & $0.41 \rightarrow 0.35$ & $0.64 \rightarrow 0.58$ & $0.40 \rightarrow 0.34$ & $0.48 \rightarrow 0.38$ & $0.45 \rightarrow 0.41$ \\
\hline BGE & $0.40 \rightarrow 0.28$ & $0.26 \rightarrow 0.15$ & $0.22 \rightarrow 0.21$ & $0.26 \rightarrow 0.12$ & $0.32 \rightarrow 0.13$ & $0.19 \rightarrow 0.11$ \\
\hline \multicolumn{7}{|c|}{ Relative consumption of LMW DOM during incubation } \\
\hline LMW DOM (\% of BCD) & 125.2 & 46.8 & 14.9 & 16.8 & 68.6 & 1.9 \\
\hline CA (\% of BCD) & 94.8 & 16.9 & 7.7 & 14.8 & 62.3 & 0.0 \\
\hline AA (\% of BCD) & 12.6 & 19.2 & 3.5 & 1.1 & 4.0 & 1.9 \\
\hline $\mathrm{CH}$ (\% of BCD) & 17.8 & 10.6 & 3.8 & 0.9 & 2.3 & 0.0 \\
\hline
\end{tabular}

Abbreviations: a254/a365, ratio between absorbance at 254 and $365 \mathrm{~nm}$; AA, free amino acids; BCD, bacterial carbon demand (sum of bacterial production and respiration); BGE, bacterial growth efficiency; CA, carboxylic acids; $\mathrm{CH}$, simple carbohydrates; DOM, dissolved organic matter; LMW DOM, low-molecular-weight DOM (sum of CA, AA and CH).

Arrows indicate the change from the beginning to the end of 2 -week bacterial incubations at $20^{\circ} \mathrm{C}$.
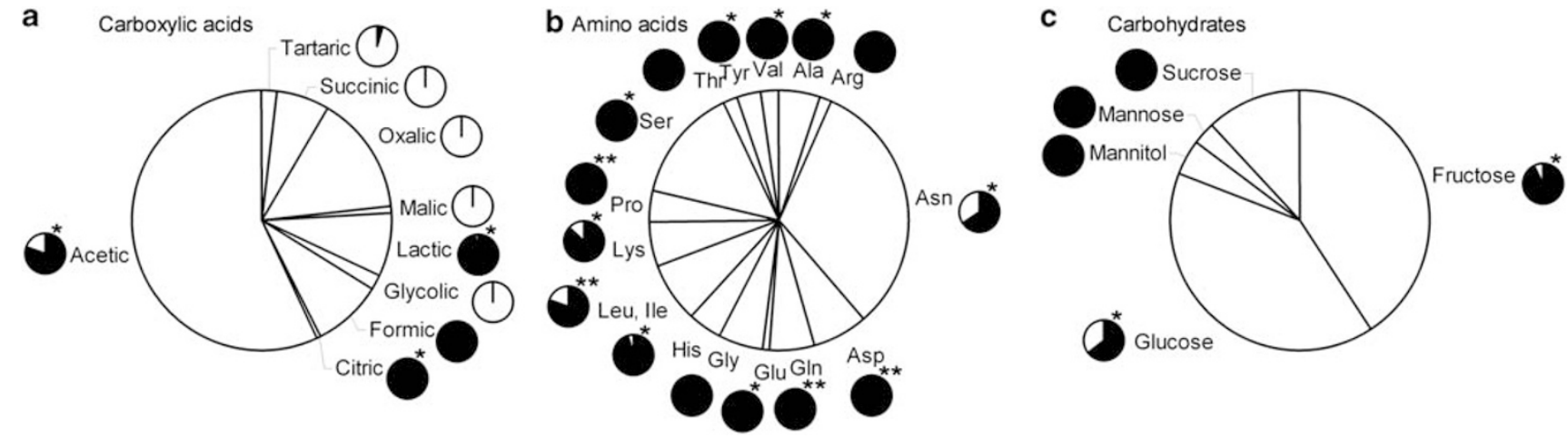

Figure 1 The average composition of simple free (a) carboxylic acids, (b) amino acids and (c) carbohydrates in drainage from three boreal catchments sampled twice. Large circles show the relative concentration of carbon from different compounds and small circles show 'bioavailability' (filled area), that is, reduction in concentration as a result of 2-week bioassays. Significant reductions (paired $t$-tests): ${ }^{*} P<0.05 ;{ }^{*} P<0.01$.

organic LMW compounds, with higher values in the forest stream than in the mire outlet, and with higher values before the bacterial incubations than after (Table 1). The relationship between a254/a365 and the percentage of DOM constituted by free organic LMW compounds was $y=0.11 x+3.83$ $\left(R^{2}=0.64, n=12, P<0.01\right)$.

Bacterial consumption of $\mathrm{CA}, \mathrm{AA}$ and $\mathrm{CH}$, calculated from reductions in concentrations during incubation, together constituted more than $100 \%$ of the BCD in the forest stream in early spring (Table 1). This was primarily a result of high assimilation of CA, mainly acetate. At the falling limb of the spring flood, the corresponding value was $47 \%$ in the forest stream. Here, the consumption of CA was lower, compared with in early spring, and of the same magnitude as the consumption of $\mathrm{AA}$ and $\mathrm{CH}$. In the mire outlet, only $15-17 \%$ of BCD constituted of free organic LMW compounds on both occasions. In the lake outlet samples, consumption of LMW DOM amounted to $69 \%$ of BCD in early spring, but only $2 \%$ in late spring. This extreme difference was reflected by a large difference in the presence of labile CA, especially acetate. 


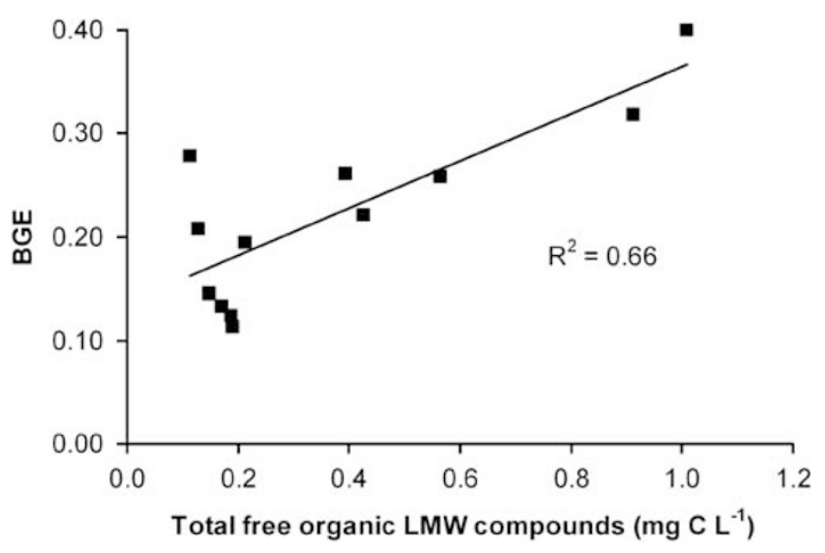

Figure 2 Bacterial growth efficiency (BGE) in relation to lowmolecular-weight dissolved organic matter (LMW DOM; $y=0.23 x+0.14, R^{2}=0.66, n=12, P<0.01$ ), based on initial and final values from duplicate 2 -week bioassays using drainage water from three boreal catchments.

\section{Discussion}

The relationship between BGE and the total amount of free organic LMW compounds (Figure 2) suggests that consumption of simple, labile substrates is a major influence on bacterial metabolism in boreal aquatic streams. Various compounds of CA, AA and $\mathrm{CH}$ were depleted during the 2-week incubation (Figure 1), simultaneous with a decrease in average BGE (mean of all six incubations) from 0.28 to 0.17 (Table 1). The BGE was within the range reported for bacterial use of DOM at different degrees of degradation, in which BGE on fresh DOM from forest soil solutions can be as high as $0.40-0.50$ (Lennon and Pfaff, 2005; Berggren et al., 2007) and BGE on DOM that has been aged for years usually is lower than 0.10 (Eiler et al., 2003). We argue that $\mathrm{CA}, \mathrm{AA}$ and $\mathrm{CH}$ were preferentially taken up and incorporated into bacterial cells with high efficiency, leaving a more recalcitrant DOM pool to be metabolized with lower efficiency at the end of the incubations. Support for the assumption that LMW DOM was incorporated into bacterial biomass was given by the acetate re-addition test (see Methods).

Measured LMW compounds constituted 1.1-8.4\% of the total DOM. The positive correlation between their share of DOM and a254/a365 indicates that LMW DOM, although being a small share of total DOM, was negatively coupled with the average molecular weight of the total DOM pool (Strome and Miller, 1978; Dahlén et al., 1996). Despite the dominance by DOM from terrestrial sources in the study streams, the observed concentrations of dissolved free $\mathrm{CH}$ and $\mathrm{AA}$ were of the same magnitude as those reported from much more productive aquatic systems around the world (Münster, 1993). This challenges the view that autochthonous DOM is the main source of labile LMW substrates. A considerable share of the labile LMW DOM was consumed in our 2-week incubations (Figure 1).
Consequently, fresh inputs of terrestrial LMW DOM can be an important subsidy to aquatic bacterial production, but decreases in this subsidy can be expected as an effect of LMW DOM depletion when the DOM ages during its residence in downstream aquatic ecosystems (Bergström and Jansson, 2000; Berggren et al., 2009b).

In accordance with previous studies (Fellman et al., 2008), a similar share of the DOM pool in forest and mire drainage was biodegradable, indicated by the small variation in BCD-DOM across all samples (Table 1). Nonetheless, there was a large difference in the efficiency of carbon incorporation into biomass, with BGE varying fourfold (Table 1). The highest BGE coincided with peak concentrations of free organic LMW compounds, recorded in the forest-dominated catchments Västrabäcken and Stortjärnen during early spring flood (Figure 2 and Table 1). Previous studies from the same streams in the Krycklan catchment have shown that BGE and bacterial production is higher in forest drainage, compared with mire drainage (Berggren et al., 2007; Ågren et al., 2008a; Berggren et al., 2009a). The higher average concentrations of $\mathrm{CA}, \mathrm{AA}$ and $\mathrm{CH}$ in the forest stream compared with the mire outlet (Table 1), and the correlation between BGE and free organic LWW compounds (Figure 2), show that such differences can be explained by higher concentrations of simple, labile substrates in streams draining forested catchments.

In the forest stream Västrabäcken, bacterial consumption of CA, AA and CH together amounted to $>100 \%$ of BCD in early spring (Table 1). This explains the BGE value of 0.40 observed on this occasion, which is a normal value for growth on simple LMW substrates (del Giorgio and Cole, 1998). By the end of the spring flood, the concentrations of CA in Västrabäcken were much lower and $<50 \%$ of BCD constituted of free LMW compounds. The result indicates that the forest soil pool was exhausted of labile compounds from the upper soil horizons during the spring flood (Ågren et al., 2008b). An even larger difference between the rising and falling limb of the spring flood was found in the outlet of the lake Stortjärnen. Here, the metabolism shifted from being dominated by CA in early spring to being almost totally dominated by other carbon sources than CA, AA or $\mathrm{CH}$ in late spring (Table 1). We suggest that the bacterial uptake of labile LMW substrates during water transit through the lake in combination with lower export of CA from the catchment during the later part of the spring flood, resulted in a drastic reduction of labile, simple substrates at the Stortjärnen outlet. In contrast with Västrabäcken and the Stortjärnen outlet, bacterial use of CA, AA and $\mathrm{CH}$ amounted to a similar share of BCD in the mire Kallkällsmyren outlet (15-17\%) in early and late spring (Table 1).

The difference between mire and forest soils in the release of labile LMW substrates is consistent with known DOM export dynamics of the region. In 
forested soils, the DOM pool is loaded with considerable amounts of carbohydrates and other photosynthates from mycorrhizal plant roots (Högberg et al., 2001, 2008b; Giesler et al., 2007). The rhizosphere in forest soils also provides anaerobic micro-sites that may favor production of acetic and formic acids (Giesler et al., 2007). This DOM is primarily exported to aquatic systems during episodes, when discharge is high and previously unsaturated soil horizons become activated by increased groundwater levels (Bishop et al., 2004; Petrone et al., 2007). The organic carbon leaching from mires, on the other hand, show less temporal variations in quality and often lacks the characteristics of labile aliphatic or LMW DOM (Ågren et al., 2008b). Our results show that acetate is a main component of labile LMW DOM export from both forest and mire soils, constituting $45 \%$ of the total bacterial consumption of all measured compounds together.

Besides the role of LMW DOM for meeting bacterial energy and carbon demands, AA in free forms can also be a major source of nitrogen for aquatic bacteria (Jørgensen et al., 1993). In previous incubation studies, bacterial production and BGE in the forest stream Västrabäcken was clearly limited by nitrogen whereas clear phosphorus limitation was not found in any of the streams (Berggren et al., 2007). Thus, bacterial uptake of nitrogen from AA could have contributed to the correlation between LMW DOM and BGE found in this study (Figure 2). Nutrient limitation in Västrabäcken indicates a surplus of carbon availability. Surplus carbon in bacterial substrates relative to the needs of nutrients can lead to dispose of excess carbon by increased respiration or by release of, for example,, extracellular polysaccharides (Decho, 1990; Hessen and Anderson, 2008). Release of extracellular polysaccharides might have taken place in the early spring sample from the forest stream, explaining that the bacterial uptake of LMW substrates was $125 \%$ of BCD, that is, slightly higher than the carbon demand for respiration and production (Table 1).

This study focuses on the snow melt flood in spring, which is the major hydrological event of the year, contributing $50-70 \%$ of the annual runoff in the area (Laudon et al., 2004) and replacing the entire water volume in the vast majority of Swedish boreal lakes (Lindström et al., 2006). The average labile part of free LMW compounds in spring drainage from mire and forest catchments was 0.31 and $0.60 \mathrm{mg} \mathrm{CL}^{-1}$, respectively (Table 1). At a BGE of $0.28-0.40$, suggested by forest stream data from early spring when BCD was fully met by LMW DOM (Tables 1), this corresponds to a bacterial production of 0.09-0.24 $\mathrm{mg} \mathrm{CL}^{-1}$. Bacterial production in northern unproductive lakes is normally $<5 \mu \mathrm{g} \mathrm{CL} \mathrm{L}^{-1} \mathrm{~d}^{-1}$ in spring (Tulonen, 1993; Bergström and Jansson, 2000; Karlsson et al., 2001), suggesting that free LMW compounds in boreal spring flood drainage can potentially support all in situ bacterial produc- tion in receiving lakes during periods of weeks to months after the spring flood.

In summary, we show that all allochthonous DOM should not be regarded as recalcitrant. On the contrary, LMW DOM of terrestrial origin was a readily available and quantitatively important subsidy of bacterioplankton metabolism in the studied boreal fresh water. The use of LMW DOM, especially acetate, contributed to high BGE and, thus, to high rates of bacterial production. LMW DOM was most abundant in drainage water from forests that dominate the vegetation of boreal catchments. The unproportionally large effects of LMW compounds (high share of bacterial use of carbon despite the low share of total DOM) means that LMW DOM can be an important base for bacterial production in boreal streams and lakes, especially during and after high flow episodes when large amounts of DOM are exported from terrestrial systems. Considering that bacterioplankton are a link in aquatic food chains (Azam et al., 1983; Jansson et al., 2007), we suggest that export of terrestrial LMW DOM has consequences for the function of aquatic food webs.

\section{Acknowledgements}

The financial support for this work was provided by the Swedish Research Council for Environment, Agricultural Sciences and Spatial Planning (FORMAS) within the LEREC program and the Swedish Research Council (VR). The Knut and Alice Wallenberg Foundation provided resources for the gas chromatography equipment that was used to measure respiration.

\section{References}

Ågren A, Berggren M, Laudon H, Jansson M. (2008a). Terrestrial export of highly bioavailable carbon from small boreal catchments in spring floods. Freshwat Biol 53: 964-972.

Ågren A, Buffam I, Jansson M, Laudon H. (2007). Importance of seasonality and small streams for the landscape regulation of dissolved organic carbon export. J Geophys Res Biogeosciences 112: G03003, doi:10.1029/2006JG000381.

Ågren A, Buffam I, Berggren M, Bishop K, Jansson M, Laudon H. (2008b). Dissolved organic carbon characteristics in boreal streams in a forest-wetland gradient during the transition between winter and summer. J Geophys Res Biogeosciences 113: G03031, doi:10.1029/2007JG000674.

Azam F, Fenchel T, Field JG, Meyer-Reil RA, Thingstad TF. (1983). The ecological role of water-column microbes in the sea. Mar Ecol-Prog Ser 10: 257-263.

Berggren M, Laudon H, Jansson M. (2007). Landscape regulation of bacterial growth efficiency in boreal freshwaters. Global Biogeochem Cycles 21: GB4002, doi:10.1029/2006GB002844.

Berggren M, Laudon H, Jansson M. (2009a). Hydrological control of organic carbon support for bacterial growth in boreal headwater streams. Microb Ecol 57: 170-178. 
Berggren M, Laudon H, Jansson M. (2009b). Aging of allochthonous organic carbon regulates bacterial production in unproductive boreal lakes. Limnol Oceanogr 54: 1333-1342.

Bergström AK, Jansson M. (2000). Bacterioplankton production in humic Lake örtrasket in relation to input of bacterial cells and input of allochthonous organic carbon. Microb Ecol 39: 101-115.

Bertilsson S, Tranvik LJ. (1998). Photochemically produced carboxylic acids as substrates for freshwater bacterioplankton. Limnol Oceanogr 43: 885-895.

Bishop K, Seibert J, Köhler S, Laudon H. (2004). Resolving the double paradox of rapidly mobilized old water with highly variable responses in runoff chemistry. Hydrol Process 18: 185-189.

Chen WH, Wangersky PJ. (1996). Rates of microbial degradation of dissolved organic carbon from phytoplankton cultures. J Plankton Res 18: 1521-1533.

Cole JJ, Findlay S, Pace ML. (1988). Bacterial production in fresh and saltwater ecosystems-a cross-system overview. Mar Ecol-Prog Ser 43: 1-10.

Covert JS, Moran MA. (2001). Molecular characterization of estuarine bacterial communities that use high- and low-molecular weight fractions of dissolved organic carbon. Aquat Microb Ecol 25: 127-139.

Dahlén J, Bertilsson S, Pettersson C. (1996). Effects of UV-A irradiation on dissolved organic matter in humic surface waters. Environ Int 22: 501-506.

Daniel C, Gutseit K, Anesio AM, Granéli W. (2005). Microbial food webs in the dark: independence of lake plankton from recent algal production. Aquat Microb Ecol 38: 113-123.

Decho AW. (1990). Microbial exopolymer secretions in ocean environments-their role(s) in food webs and marine processes. Oceanogr Mar Biol 28: 73-153.

del Giorgio PA, Cole JJ. (1998). Bacterial growth efficiency in natural aquatic systems. Annu Rev Ecol Syst 29: $503-541$

Drakare S, Blomqvist P, Bergström AK, Jansson M. (2002). Primary production and phytoplankton composition in relation to DOC input and bacterioplankton production in humic Lake örtrasket. Freshwat Biol 47: 41-52.

Eiler A, Langenheder S, Bertilsson S, Tranvik LJ. (2003). Heterotrophic bacterial growth efficiency and community structure at different natural organic carbon concentrations. Appl Environ Microbiol 69: 3701-3709.

Fellman JB, D'Amore DV, Hood E, Boone RD. (2008). Fluorescence characteristics and biodegradability of dissolved organic matter in forest and wetland soils from coastal temperate watersheds in southeast Alaska. Biogeochemistry 88: 169-184.

Fogg GE. (1983). The ecological significance of extracellular products of phytoplankton photosynthesis. Bot Mar 26: 3-14.

Giesler R, Högberg MN, Strobel BW, Richter A, Nordgren A, Högberg P. (2007). Production of dissolved organic carbon and low-molecular weight organic acids in soil solution driven by recent tree photosynthate. Biogeochemistry 84: 1-12.

Hellebust JA. (1974). Extracellular products. In: Steward ND (ed). Algal Physiology and Biochemistry. University of California Press: Berkeley, CA, pp 838-863.

Hessen DO, Anderson TR. (2008). Excess carbon in aquatic organisms and ecosystems: physiological, ecological, and evolutionary implications. Limnol Oceanogr 53: 1685-1696.
Hopkinson CS, Buffam I, Hobbie J, Vallino J, Perdue M, Eversmeyer B et al. (1998). Terrestrial inputs of organic matter to coastal ecosystems: an intercomparison of chemical characteristics and bioavailability. Biogeochemistry 43: 211-234.

Högberg P, Nordgren A, Buchmann N, Taylor AFS, Ekblad A, Högberg MN et al. (2001). Large-scale forest girdling shows that current photosynthesis drives soil respiration. Nature 411: 789-792.

Jansson M, Bergström AK, Blomqvist P, Drakare S. (2000). Allochthonous organic carbon and phytoplankton/ bacterioplankton production relationships in lakes. Ecology 81: 3250-3255.

Jansson M, Persson L, DeRoos AM, Jones RI, Tranvik LJ. (2007). Terrestrial carbon and intraspecific size-variation shape lake ecosystems. Trends Ecol Evol 22: 316-322.

Jones RI. (1992). The influence of humic substances on lacustrine planktonic food-chains. Hydrobiologia 229: 73-91.

Jonsson A, Ström L, Åberg J. (2007). Composition and variations in the occurrence of dissolved free simple organic compounds of an unproductive lake ecosystem in northern Sweden. Biogeochemistry 82: 153-163.

Jørgensen NOG, Kroer N, Coffin RB, Yang XH, Lee C. (1993). Dissolved free amino acids, combined amino acids, and DNA as sources of carbon and nitrogen to marine bacteria. Mar Ecol-Prog Ser 98: 135-148.

Kamjunke N, Bohn C, Grey J. (2006). Utilisation of dissolved organic carbon from different sources by pelagic bacteria in an acidic mining lake. Arch Hydrobiol 165: 355-364.

Karlsson J, Jonsson A, Jansson M. (2001). Bacterioplankton production in lakes along an altitude gradient in the subarctic north of Sweden. Microb Ecol 42: 372-382.

Karlsson J, Jansson M, Jonsson A. (2002). Similar relationships between pelagic primary and bacterial production in clearwater and humic lakes. Ecology 83: $2902-2910$.

Kritzberg ES, Cole JJ, Pace MM, Granéli W. (2006). Bacterial growth on allochthonous carbon in humic and nutrient-enriched lakes: results from whole-lake C-13 addition experiments. Ecosystems 9: 489-499.

Laudon H, Köhler S, Buffam I. (2004). Seasonal TOC export from seven boreal catchments in northern Sweden. Aquat Sci 66: 223-230.

Lennon JT, Pfaff LE. (2005). Source and supply of terrestrial organic matter affects aquatic microbial metabolism. Aquat Microb Ecol 39: 107-119.

Lindström ES, Forslund M, Algesten G, Bergström AK. (2006). External control of bacterial community structure in lakes. Limnol Oceanogr 51: 339-342.

Münster U. (1993). Concentrations and fluxes of organic carbon substrates in the aquatic environment. Anton Leeuw Int J G 63: 243-274.

Petrone K, Buffam I, Laudon H. (2007). Hydrologic and biotic control of nitrogen export during snowmelt: a combined conservative and reactive tracer approach. Water Resour Res 43: W06420, doi:10.1029/ 2006WR005286.

Roehm CL, Giesler R, Karlsson J. (2009). Bioavailability of terrestrial organic carbon to lake bacteria: the case of a degrading subarctic permafrost mire complex. $J$ Geophys Res Biogeosciences 114: G03006, doi: 10.1029/2008JG000863. 
Rosenstock B, Simon M. (2001). Sources and sinks of dissolved free amino acids and protein in a large and deep mesotrophic lake. Limnol Oceanogr 46: 644-654.

Schumacher M, Christl I, Vogt RD, Barmettler K, Jacobsen C, Kretzschmar R. (2006). Chemical composition of aquatic dissolved organic matter in five boreal forest catchments sampled in spring and fall seasons. Biogeochemistry 80: 263-275.

Smith DC, Azam F. (1992). A simple, economical method for measuring bacterial protein synthesis rates in seawater using 3H-leucine. Mar Microb Food Webs 6: 107-114.

Strome DJ, Miller MC. (1978). Photolytic changes in dissolved humic substances. Verh Internat Verein Limnol 20: 1248-1254.

Tranvik LJ. (1998). Degradation of dissolved organic matter in humic waters by bacteria. In: Tranvik LJ, Hessen DO (eds). Aquatic Humic Substances: Ecology and Biogeochemistry. Springer-Verlag: Berlin, pp 259-283.

Tranvik LJ, Jørgensen NOG. (1995). Colloidal and dissolved organic matter in lake water-carbohydrate and amino acid composition, and ability to support bacterial growth. Biogeochemistry 30: 77-97.

Tulonen T. (1993). Bacterial production in a mesohumic lake estimated from [C-14] leucine incorporation rate. Microb Ecol 26: 201-217.

Wetzel RG. (1995). Death, detritus, and energy flow in aquatic ecosystems. Freshwat Biol 33: 83-89. 